\title{
Nieredukowalna złożoność: problem dla ewolucjonizmu darwinowskiego *
}

\section{Zarys hipotezy inteligentnego projektu}

W swoim doniosłym dziele O powstawaniu gatunków Darwin zamierzał wyjaśnić to, czego nikomu nie udało się wytłumaczyć wcześniej - jak dzięki prostym prawom przyrody powstała różnorodność i złożoność świata ożywionego. Miała mu w tym pomóc, oczywiście, teoria ewolucji na drodze doboru naturalnego. Krótko mówiąc, Darwin zaobserwował, że u wszystkich gatunków występuje różnorodność. Niektóre osobniki danego gatunku są, na przykład, większe od innych, niektóre szybsze, a jeszcze inne mają jaśniejsze ubarwienie. Wiedział on, że nie wszystkie narodzone organizmy przetrwały, aby się rozmnażać, po prostu dlatego, że nie było dla nich wystarczającej ilości pożywienia. Darwin rozumował więc, że przeżywają i rozmnażają się te organizmy, którym przypadkowa zmiana dała przewagę $\mathrm{w}$ walce o życie. Jeśli ta zmiana została odziedziczona, to charakterystyka gatunku mogła się z czasem zmienić; po długim okresie mogły nastąpić duże zmiany.

*Michael J. Bene, „Irreducible Complexity: Obstacle to Darwinian Evolution”, w: Michael Ruse and William A. Dembski (eds.), Debating Design: From Darwin to DNA, Cambridge University Press, Cambridge 2004, s. 352-370. Z języka angielskiego za zgodą Autora przełożył Dariusz Sagan. Recenzent: Grzegorz NowaK, Zakład Biochemii UMCS, Lublin. 
Była to elegancka idea i wielu ówczesnych uczonych szybko zauważyło, że może ona wyjaśnić wiele spraw dotyczących biologii. Jednakże wciąż pozostawał ważny powód do powściągania sądów na temat tego, czy owa idea faktycznie może wyjaśnić wszystkie aspekty biologii: nie znano jeszcze fundamentu życia. W czasach Darwina atomy i molekuły ciągle stanowiły tylko konstrukty teoretyczne - nie było pewności, czy rzeczywiście istnieją. Wielu naukowców ery darwinowskiej uważało komórkę za zwykłą kulkę protoplazmy, za coś w rodzaju kawałka mikroskopijnej galaretki. Darwin i jemu współcześni nie znali złożonego molekularnego fundamentu życia.

W ciągu minionych stu lat naukowcy dowiedzieli się dużo więcej o komórce, a także - zwłaszcza w ciągu ostatnich pięćdziesięciu lat wiele o molekularnych podstawach życia. Dzięki odkryciu spiralnej struktury DNA, kodu genetycznego, złożonej, nieregularnej budowy białek, a także wielu innym odkryciom, lepiej zrozumieliśmy skomplikowane struktury, które są niezbędne do utrzymania życia. Zobaczyliśmy, że komórkę napędzają mechanizmy - dosłownie, mechanizmy utworzone $\mathrm{z}$ molekuł. W komórce znajdują się mechanizmy, dzięki którym się ona porusza, mechanizmy zasilające transport składników pokarmowych, jak również mechanizmy, dzięki którym się ona broni.

W świetle ogromnego postępu nauki, jaki poczyniła ona, odkąd Darwin zaproponował swoją teorię, zasadne jest pytanie, czy nadal stanowi ona dobre wyjaśnienie życia? W Darwin's Black Box: The Biochemical Challenge to Evolution ${ }^{1}$ [Czarna skrzynka Darwina: biochemiczne wyzwanie dla ewolucjonizmu] argumentowałem, że tak nie jest. Główną trudność dla mechanizmów darwinowskich stanowi to, że wiele systemów w komórce jest, jak je nazywam, „nieredukowalnie złożonych". Definiuję układ nieredukowalnie złożony jako pojedynczy system złożony z poszczególnych dobrze dopasowanych, oddziałujących ze sobą części, które mają udział w pełnieniu

\footnotetext{
${ }^{1}$ Michael J. Behe, Darwin's Black Box: The Biochemical Challenge to Evolution, The Free Press, New York 1996.
} 
podstawowej funkcji układu. Usunięcie jakiejkolwiek z tych części powoduje, że system przestaje sprawnie funkcjonować. ${ }^{2}$ Jako przykładu układu nieredukowalnie złożonego - wziętego z życia codziennego - użyłem pułapki na myszy, którą można kupić w sklepie z artykułami żelaznymi. Zazwyczaj pułapki takie mają liczne części: sprężynę, drewnianą podstawę, młoteczek i inne. Jeśli usunie się jakąś część z pułapki, to nie złapie ona myszy. Pozbawiona sprężyny, młoteczka czy innych części, pułapka nie funkcjonuje choćby w połowie, ani nawet w ćwierci tak dobrze jak zwykle: mamy wtedy zepsutą pułapkę na myszy, która w ogóle nie działa.

Z powodu, który podkreślał sam Darwin, systemy nieredukowalnie złożone bardzo trudno wpasować w ramy darwinizmu. W O powstawaniu gatunków Darwin napisał, że „Jeśliby można było wykazać, że istnieje jakikolwiek narząd złożony, który nie mógłby być utworzony na drodze licznych, następujących po sobie, drobnych przekształceń teoria moja musiałaby absolutnie upaść. Wszelako takiego przykładu nie znalazłem". ${ }^{3}$ Darwin podkreślał tu, że jego teoria jest gradualistyczna. Dobór naturalny musiał udoskonalać systemy w małych krokach przez długi czas, ponieważ jeśli układy te udoskonalałyby się zbyt szybko lub w dużych krokach, to zaczęłoby to wyglądać tak, jakby owym procesem kierowało coś innego niż dobór naturalny. Trudno jednak zrozumieć, jak takie urządzenie, jak pułapka na myszy, mogło powstać stopniowo za pomocą czegoś zbliżonego do procesu darwinowskiego. Sama sprężyna, na przykład, lub podstawa nie złapie myszy, a poprzez dodanie jakiegoś elementu do tej pierwszej niefunkcjonalnej części także nie powstanie pułapka. Wygląda więc na to, że nie-

\footnotetext{
${ }^{2}$ Por. Michael J. Behe, „Reply to My Critics: A Response to Reviews Of Darwin's Black Box: The Biochemical Challenge to Evolution", Biology and Philosophy 2001, vol. 16, s. $685-709$.

${ }^{3}$ Karol $D_{\text {ARwIN, }}$ O powstawaniu gatunków drogą doboru naturalnego, czyli o utrzymaniu się doskonałych ras $w$ walce o byt, $\mathrm{z}$ języka angielskiego przełożyli Szymon Dickstein i Józef Nusbaum, Ediciones Altaya Polska \& DeAgostini Polska, Warszawa 2001, s. 200.
} 
redukowalnie złożone układy biologiczne stanowią duży problem dla ewolucjonizmu darwinowskiego.

Powstaje więc pytanie: czy w komórce są jakieś systemy nieredukowalnie złożone? Czy istnieją jakieś nieredukowalnie złożone mechanizmy molekularne? Tak, jest ich wiele. W Darwin's Black Box omawiałem kilka przykładów nieredukowalnie złożonych układów biochemicznych: rzęskę eukariotyczną, transport międzykomórkowy i wiele innych. Tutaj opiszę krótko tylko wić bakteryjną, ${ }^{4}$ ponieważ łatwo zobaczyć, że jej struktura stanowi trudność dla ewolucjonizmu darwinowskiego (zobacz rys. 1). Wić można przyrównać do silnika zaburtowego, używanego przez bakterie do pływania. Była to pierwsza prawdziwie obrotowa struktura, jaką odkryto w przyrodzie. Składa się ona $\mathrm{z}$ długiego spiralnego ogona,który działa jak śruba; wirując przesuwa się w płynie, dzięki czemu bakteria może się poruszać. Owa śruba jest pośrednio przymocowana do wału napędowego przy pomocy czegoś, co nazywane jest obszarem haczykowatym, który działa jak uniwersalne łącze. Wał napędowy jest przytwierdzony do silnika, który zasila obroty za pomocą przepływu kwasu lub jonów sodu z zewnątrz do wewnątrz komórki. Pracujący silnik zaburtowy musi być na stałe umocowany na motorówce; podobnie, są białka, które działają jak stator utrzymujący wić w jednym miejscu. Inne białka funkcjonują jak tuleje umożliwiające wałowi napędowemu przenikanie przez membranę bakteryjną. Badania wykazały, że do wytworzenia funkcjonalnej wici w komórce potrzeba 30-40 białek. Około połowa z nich składa się na ukończoną strukturę wici, a pozostałe są konieczne przy jej konstruowaniu. Jeśli zabraknie niemal któregokolwiek z tych białek - części, która działa jak śruba, wału napędowego, haka i tak dalej - nie zostanie zbudowana funkcjonalna wić.

Jak w przypadku pułapki na myszy, trudno zrozumieć, w jaki sposób przesiewający przypadkowe mutacje darwinowski, gradualistycz-

\footnotetext{
${ }^{4}$ David J. DeRossier, „The Turn of the Screw: The Bacterial Flagellar Motor”, Cell 1998, vol. 93, s. 17-20; Lucy Shapiro, „The Bacterial Flagellum: From Genetic Network to Complex Architecture”, Cell 1995, vol. 80, s. 525-527.
} 
ny proces doboru naturalnego mógł wytworzyć wić bakteryjną, ponieważ wymaganych jest wiele części, zanim zacznie ona funkcjonować. Sam hak lub wał napędowy nie będą działać jak urządzenie napędzające. Sytuacja wygląda faktycznie o wiele gorzej, niż się wydaje $\mathrm{z}$ tego pobieżnego opisu. Jest tak z kilku powodów. Po pierwsze, z funkcjonalną wicią połączony jest skomplikowany system kontrolny, który mówi jej, kiedy ma rotować i kiedy przestać, a czasem, kiedy się odwrócić i obracać się w przeciwnym kierunku. Umożliwia to bakterii poruszanie się w stronę odpowiedniego sygnału, jak i w stronę przeciwną, zamiast w kierunku przypadkowym, co ułatwiałoby jej popłynięcie w niewłaściwym kierunku. Problem wyjaśnienia pochodzenia wici nie ogranicza się zatem do niej samej, lecz obejmuje także sprzęgnięty z nią system kontrolny.

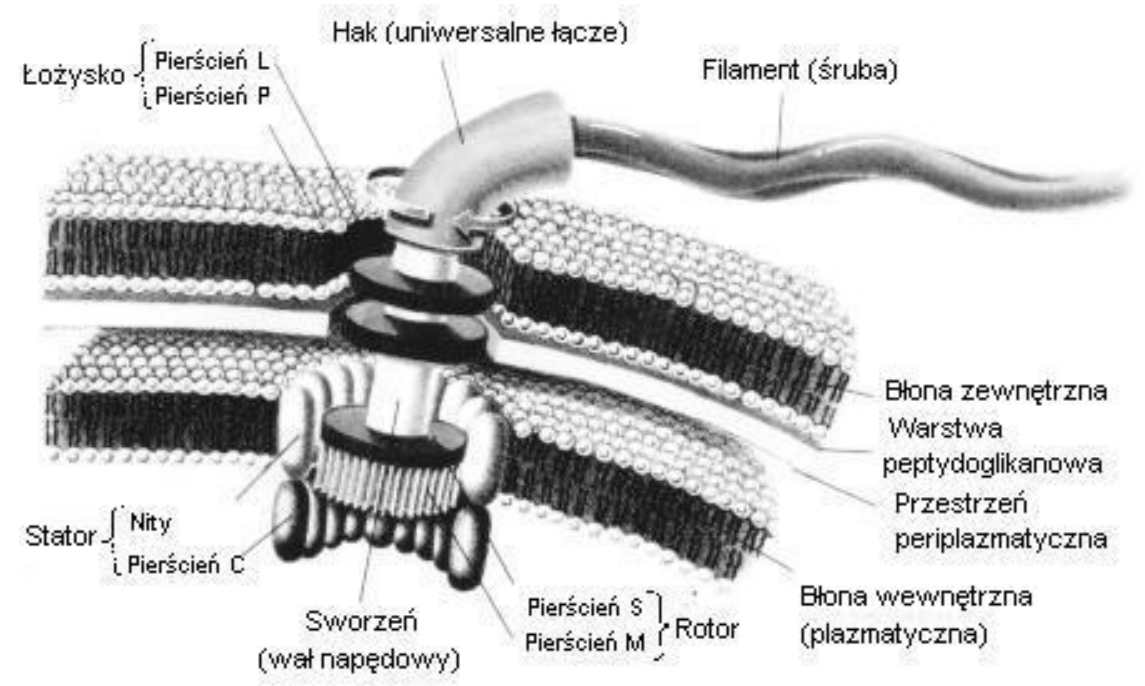

Rys. 1. Wić bakteryjna. Reprodukowane z: D. VOET and J.G. VOET, Biochemistry, 2nd edition, John Wiley \& Sons, New York 1995, rys. 34-84, za zgodą Wydawnictwa Johna Wileya i Donalda Voeta, którego przedstawiciele życzyli sobie, aby podkreślić, iż „jest to bardziej artystyczna wizja niż zdjęcie czy rysunek rzeczywistej wici”. 
Po drugie, subtelniejszy problem stanowi to, w jaki sposób poszczególne części wici złożyły się w jedną całość. Analogia do silnika zaburtowego jest nieadekwatna pod jednym względem: generalnie silnik zaburtowy montuje człowiek - inteligentny czynnik określający, które części mają się ze sobą łączyć. Jednakże informacja potrzebna do złożenia wici bakteryjnej (czy, w rzeczywistości, wszystkich pozostałych biologicznych mechanizmów molekularnych) zawiera się w białkach tworzących samą tę strukturę. Niedawno opublikowana praca pokazuje, że proces powstawania wici jest nadzwyczaj wyrafinowany i złożony. ${ }^{5}$ Gdy białka nie zawierają tej informacji, wić w ogóle nie powstaje. Dlatego, nawet jeśli mielibyśmy hipotetyczną komórkę, w której byłyby białka homologiczne do wszystkich części wici (być może wykonujące inne zadania niż napędzanie), lecz brakowałoby informacji mówiącej o tym, jak mają się one złożyć w wić, to i tak nie otrzymalibyśmy odpowiedniej struktury. Problem nieredukowalności nie zniknie.

Wyciągnąłem stąd wniosek, że procesy darwinowskie nie stanowią obiecującego wyjaśnienia dla wielu systemów biochemicznych w komórce. Przeciwnie, zauważyłem, że kiedy przyjrzymy się oddziaływaniom składników wici, rzęski czy innych nieredukowalnie złożonych układów komórkowych, wyglądają one tak, jakby zostały zaprojektowane - celowo zaprojektowane przez jakiś inteligentny czynnik. Wskazujące na projekt cechy tych systemów to te same cechy, które są przeszkodą dla wyjaśnień darwinowskich: chodzi o specyficzne oddziaływanie wielu składników, dzięki któremu uzyskuje się funkcję wykraczającą poza zasięg poszczególnych składników z osobna. Struktura logiczna argumentu przemawiającego za projektem jest indukcyjna: zawsze, gdy natykamy się na takie bardzo specyficzne interakcje w życiu codziennym, czy to w pułapce na myszy, czy gdziekolwiek indziej, bezbłędnie rozpoznajemy, że owe systemy utworzono celowo - zostały zaprojektowane. W komórce znajdujemy

\footnotetext{
${ }^{5}$ K. Yonekura, S. Maki, D.G. Morgan, D.J. DeRossier, F. Vonderviszt, K. Imada \& K. Namba, „The Bacterial Flagellar Cap as the Rotary Promoter of Flagellin Self-Assembly”, Science 2000, vol. 290, s. 2148-2152.
} 
obecnie układy o podobnej złożoności. Skoro żadne inne wyjaśnienie nie jest adekwatne, sugeruję, by rozszerzyć ową indukcję na mechanizmy molekularne i wysunąć hipotezę, że zostały one celowo zaprojektowane.

\section{Nieporozumienia związane z konsekwencjami, jakie pociąga za sobą hipoteza projektu}

Hipoteza inteligentnego projektu (ID) jest dość kontrowersyjna. Jest tak przeważnie z powodu jej filozoficznego i teologicznego wydźwięku. Od czasu opublikowania Darwin's Black Box wielu naukowców i filozofów próbowało obalić główny argument tej książki. W najlepszym wypadku uważam te próby obalenia za nieprzekonujące. Wręcz przeciwnie, sądzę, że niektóre domniemane kontrprzykłady dla projektu są mimowolnie pouczające pod tym względem, iż nie tylko nie stanowią argumentu na rzecz wystarczalności hipotezy doboru naturalnego, lecz wyraźnie ukazują trudność, jaką nieredukowalna złożoność sprawia darwinizmowi. Pokazują również, że darwiniści mają duże kłopoty $\mathrm{z}$ dostrzeganiem problemów swojej własnej teorii. Trochę dalej szczegółowo przeanalizuję dwa z owych kontrprzykładów. Jednak zanim to zrobię, ustosunkuję się do kilku błędnych wyobrażeń otaczających biochemiczny argument $\mathrm{z}$ projektu.

Przede wszystkim, ważne jest zrozumienie, że hipoteza inteligentnego projektu nie kłóci się z ewolucją per se - tj. ,ewolucją” rozumianą po prostu jako dziedziczenie z modyfikacją, gdzie jednak zostawia się otwartą kwestię jej mechanizmu. Projektant mógł przecież wybrać taki sposób działania. Zamiast na wspólnym pochodzeniu, hipoteza ID skupia się raczej na mechanizmie ewolucji - jak to wszystko się wydarzyło, przez dobór naturalny czy celowy, inteligentny projekt? 
Drugą, często przeoczaną, lecz wartą podkreślenia kwestią jest to, że inteligentny projekt bez problemu dopuszcza uznanie nawet dużej roli dla doboru naturalnego. Odporność na antybiotyki i pestycydy, białka przeciwdziałające zamarzaniu ryb i roślin, a także wiele innych rzeczy, można wyjaśnić przy pomocy mechanizmu darwinowskiego. Kluczowe twierdzenie hipotezy ID nie głosi, że dobór naturalny nie wyjaśnia niczego, ale że nie wyjaśnia wszystkiego.

Moją książkę Darwin's Black Box, w której poparłem argument z projektu, szeroko dyskutowano w licznych publikacjach. Choć poruszono wiele zagadnień, sądzę, że ogólną reakcję uczonych na argument $\mathrm{z}$ projektu dobrze i zwięźle podsumowuje niedawno wydana przez Oxford University Press książka, The Way of the Cell, której autorem jest biochemik z Colorado State University - Franklin Harold. Cytując moją książkę, Harold pisze: „Powinniśmy odrzucić, dla zasady, hipotezę inteligentnego projektu jako substytut dialogu pomiędzy przypadkiem a koniecznością (Behe 1996), ale musimy przyznać, że jak dotąd nie ma żadnych szczegółowych wyjaśnień darwinowskich dla ewolucji jakiegokolwiek systemu biochemicznego, a tylko różne pobożne spekulacje". ${ }^{6}$

Pozwólcie, że w odwróconym porządku podkreślę dwie sprawy poruszone przez Harolda. Po pierwsze, podobnie jak inni recenzenci mojej książki, ${ }^{7}$ przyznaje on, że darwiniści nie mają żadnych rzeczy205.

${ }^{6}$ Franklin M. Harold, The Way of the Cell, Oxford University Press, Oxford 2001, s.

${ }^{7}$ Na przykład mikrobiolog James Shapiro z University of Chicago napisał w National Review, że „Nie ma żadnych szczegółowych wyjaśnień dla ewolucji jakiegokolwiek podstawowego systemu biochemicznego czy komórkowego, a tylko różne pobożne spekulacje" (James A. Shapiro, „In the Details... What?”, National Review, Sept. 1996, vol. 16, s. 65 [s. 62-65]). W Nature biolog ewolucyjny z University of Chicago, Jerry Coyne, stwierdził, że „Nie ma żadnych wątpliwości, że złożoność procesów opisanych przez Behe’ego zniechęca do prowadzenia badań nad nimi i trudno będzie rozwiązać zagadkę ich ewolucji. (...) [B]yć może nigdy nie będziemy w stanie wyobrazić sobie pierwszych protoprocesów" (Jerry A. Coyne, „God in the Details”, Nature 1996, vol. 383, s. 227 [s. 227-228]). W Trends in Ecology and Evolution Tom Cavalier-Smith, biolog ewolucyjny z University of British Columbia, zamieścił następujący komentarz: „Dla żadnego z wymienionych przez Behe’ego przypadków nie ma jeszcze wyczerpującego i szczegółowego wyjaśnienia prawdopodobnych etapów ewo- 
wistych wyjaśnień dla ogromnej złożoności komórki, a tylko pozbawione empirycznego poparcia spekulacje, potocznie znane jako „takie sobie bajeczki”. W gruncie rzeczy to samo pisałem sześć lat wcześniej w Darwin's Black Box. Wtedy też napotkałem gwałtowny sprzeciw przeważnie ze strony internetowych entuzjastów darwinizmu, którzy pytali, po co w takim razie te setki czy tysiące artykułów badawczych opisujących darwinowską ewolucję nieredukowalnie złożonych systemów biochemicznych. Tworzyli oni strony internetowe, aby owe artykuły udokumentować. ${ }^{8}$

Wystarczającą odpowiedzią na podobne twierdzenia będzie dla mnie po prostu cytowana tutaj wypowiedź Harolda oraz innych recenzentów, którzy przyznają, że nie ma żadnych takich darwinowskich wyjaśnień. Ostatecznie, powinno być po sprawie, skoro wybitni uczeni, którzy nie są zwolennikami hipotezy inteligentnego projektu,

lucji obserwowanej złożoności. Problemy te rzeczywiście poważnie zaniedbywano - choć Behe nieustannie przesadnie określa to zaniedbanie takimi hiperbolami, jak «głuche i zupełne milczenie»” (Tom Cavalier-Smith, „The Blind Biochemist”, Trends in Ecology and Evolution 1997, vol. 12, s. 162 [s. 162-163]). Biolog ewolucyjny z University College w Londynie, Andrew Pomiankowski, tak powiedział w New Scientist: „Weź do ręki jakikolwiek podręcznik do biochemii, a znajdziesz może dwa lub trzy odniesienia do ewolucji. Przeczytaj któryś z nich, a będziesz miał szczęście, jeśli znajdziesz jakieś lepsze zdanie niż to, że «ewolucja dobiera molekuły najlepiej dostosowane do swoich biologicznych funkcji»" (Andrew Pomiankowski, „The God of the Tiny Gaps”, New Scientist, Sept. 1996, vol. 14, s. 44 [s. $44-$ 45]). W American Scientist biolog molekularny, Robert Dorit, zapewniał, iż „W wąskim sensie Behe ma rację argumentując, że jeszcze nie w pełni rozumiemy, jak zaszła ewolucja silni ka wici czy kaskady krzepnięcia krwi” (Robert DoRIT, „Molecular Evolution and Scientific Inquiry, Misperceived", American Scientist 1997, vol. 85, s. 474 [s. 474-475]).

${ }^{8}$ Dobrym przykładem jest strona internetowa „World of Richard Dawkins”, którą założył fan Dawkinsa - John Catalano. Oto adres tej strony: www.world-of-dawkins.com/Catalano/ box/published.htm. To tę stronę miał na myśli chemik fizyczny Peter Atkins z Uniwersytetu Oksfordzkiego, gdy w recenzji Darwin's Black Box zamieszczonej na stronie internetowej Infidels pisał: „Dr Behe twierdzi, że nauka w dużej mierze milczy na temat szczegółów ewolucji molekularnej, wyłonienia się złożonych biochemicznych szlaków i procesów, które leżą u podłoża bardziej tradycyjnych manifestacji ewolucji na poziomie organizmów. Bzdury! Istnieją setki, być może nawet tysiące artykułów naukowych poświęconych wyłącznie temu tematowi. Dla wprowadzenia w tę ważną i kwitnącą dziedzinę, a także by ujrzeć obraz wytężonej pracy naukowców, którą ona reprezentuje (zobacz pierwszy link powyżej) [sic]”. Peter W. AtкIns, „Review of Michael Behe's Darwin's Black Box”, 1998, www.infidels.org/li brary/modern/peter atkins/behe.html. 
przyznają, że pochodzenie owych układów biochemicznych w dalszym ciągu nie zostało wyjaśnione. Przerwę na chwilę, by odnotować, że uważam to za zdumiewające wyznanie wobec teorii, która dominuje w biologii od tak dawna. Fakt, że teoria Darwina okazała się mało owocna w wyjaśnianiu molekularnej podstawy życia - pomimo długiego jej panowania jako fundamentalnej teorii w biologii - wyraźnie wskazuje na to, że nie jest ona właściwą ramą pojęciową dla zrozumienia pochodzenia złożoności życia.

Po drugie, Harold najwyraźniej sądzi, że istnieje pewna zasada zakazująca nam badania hipotezy inteligentnego projektu, mimo iż idea projektu przychodzi od razu do głowy w momencie, gdy spogląda się na rysunek wici (rys. 1) lub innych złożonych układów biochemicznych. Cóż to za zasada? Harold nigdzie tego nie wyjaśnia, sądzę jednak, że można ją przedstawić skrótowo tak: projekt zdaje się silnie wykraczać poza przyrodę. Niesie skojarzenia filozoficzne i teologiczne, a to jest dla wielu ludzi niewygodne. Uważają oni, że nauka powinna unikać teorii, która wykracza poza przyrodę i dlatego chcą odrzucić hipotezę inteligentnego projektu już na samym początku.

Zupełnie nie zgadzam się z tym poglądem i uważam, że jest on tchórzliwy. Moim zdaniem nauka powinna iść za świadectwami empirycznymi niezależnie od tego, dokąd one prowadzą. To jedyna droga do osiągnięcia postępu. Co więcej, nie tylko hipoteza inteligentnego projektu, lecz każda teoria usiłująca wyjaśnić, jak powstało życie, będzie niosła filozoficzne i teologiczne skojarzenia. Na przykład, oksfordzki biolog Richard Dawkins wypowiedział słynne słowa, iż „Darwin sprawił, że ateizm jest w pełni satysfakcjonujący intelektualnie". ${ }^{9}$ Nieco mniej słynne słowa napisał Kenneth Miller: „[Bóg] posłużył się ewolucją jako narzędziem dla naszego wyzwolenia”. ${ }^{10}$ Stuart Kauff-

\footnotetext{
${ }^{9}$ Richard Dawkins, Ślepy zegarmistrz czyli, jak ewolucja dowodzi, że świat nie zostal zaplanowany, przeł. Antoni Hoffman, Biblioteka Myśli Wspótczesnej, Państwowy Instytut Wydawniczy, Warszawa 1994, s. 28.

${ }^{10}$ Kenneth R. Miller, Finding Darwin's God: A Scientist's Search for common ground between God and Evolution, Cliff Street Books, New York 1999, s. 253.
} 
man, czołowy teoretyk złożoności, uważa, że darwinizm nie jest w stanie wyjaśnić wszystkich aspektów biologii: „Darwinizm nie wystarczy... [D]obór naturalny nie może być jedynym źródłem porządku widocznego w świecie". ${ }^{11}$ Sądzi on jednak, że jego teoria w jakiś sposób pokaże, iż jesteśmy „we Wszechświecie u siebie”. Wszystkie teorie dotyczące pochodzenia niosą skojarzenia filozoficzne i teologiczne. Skojarzeń takich nie da się żadnym sposobem uniknąć przy wyjaśnianiu życia.

Dla niektórych ludzi inne źródło trudności dotyczy tego, jak systemy biochemiczne mogły zostać zaprojektowane. Powszechnie błędnie się rozumie, że zaprojektowane układy musiały zostać stworzone od zera i momentalnie. Ale niekoniecznie tak musi być. Proces projektowania może być o wiele subtelniejszy. W rzeczywistości, w ogóle nie musiał on naruszać żadnego prawa natury. Rozważmy jedną z możliwości. Przypuśćmy - jak zrobiłaby większość ludzi - że projektant faktycznie jest Bogiem. Skoro tak, to - jak wykazuje Kenneth Miller w swojej książce Finding Darwin's God:

Niezdeterminowana natura zdarzeń kwantowych umożliwiłaby sprytnemu i wnikliwemu Bogu wpływanie na wydarzenia w sposób przemożny, lecz niewykrywalny metodami nauki. Wydarzenia mogłyby obejmować występowanie mutacji [...] a nawet przeżywalność pojedynczych komórek i organizmów, na którą mają wpływ przypadkowe procesy rozpadu radioaktywnego. ${ }^{12}$

Choć Miller nie uważa, że kierownictwo jest konieczne w procesie ewolucji, to gdyby było - jak mniemam - Bóg miałby otwartą drogę do projektowania życia bez omijania praw natury. Jeśli zdarzeniami kwantowymi, takimi jak rozpad radioaktywny, nie rządzą prawa przyczynowe, to wywarcie wpływu na takie zdarzenia nie łamie żadnego

\footnotetext{
${ }^{11}$ Stuart A. Kaufrman, At Home in the Universe: The Search for Laws of Self-organization and Complexity, Oxford University Press, New York 1995, s. viii.

${ }^{12}$ Miller, Finding Darwin's God..., s. 241.
} 
prawa natury. Zarówno mnie jako teiście, jak i Millerowi, wydaje się to absolutnie możliwe. Dodam jednak, że taki proces jest równoznaczny $z$ inteligentnym projektem, a nie ewolucją darwinowską. Ponadto, chociaż możemy być niezdolni do wykrywania kwantowych manipulacji, możemy śmiało wnioskować, że jakaś ukończona struktura została zaprojektowana.

\section{Nieporozumienia dotyczące domniemanych dróg powstawania nieredukowalnych systemów biochemicznych}

Rozważmy hipotetyczny układ, w którym białka homologiczne do wszystkich części nieredukowalnie złożonego mechanizmu molekularnego z początku pełniły inne indywidualne funkcje w komórce. Czy nieredukowalny system mógł $\mathrm{w}$ takim przypadku zostać złożony $\mathrm{z}$ pojedynczych składników, które pierwotnie funkcjonowały osobno jak proponują niektórzy darwiniści? Niestety, jak pisałem w Darwin's Black Box, ${ }^{13}$ zarysowany powyżej obraz znacznie upraszcza ten problem. Tutaj analogie do pułapek na myszy trochę zawodzą, ponieważ części układu molekularnego muszą automatycznie odnaleźć siebie nawzajem w komórce. Nie może ich ułożyć pewien inteligentny czynnik, jak to ma miejsce w przypadku pułapki na myszy. Aby odnaleźć się wzajemnie w komórce, oddziałujące ze sobą części muszą mieć powierzchnie ukształtowane tak, żeby bardzo dobrze do siebie pasować, jak to zobrazowałem na rysunku 2. Pierwotnie jednak funkcjonujące $\mathrm{z}$ osobna składniki nie miałyby komplementarnych powierzchni. Wszystkie oddziałujące ze sobą powierzchnie wszystkich składników musiałyby więc zostać dopasowane do siebie, zanim zaczęłyby działać razem. Dopiero wtedy mogłaby pojawić się nowa funkcja złożonego systemu. Dlatego mocno podkreślam, że problem nieredukowalności nie znika, nawet jeśli pojedyncze białka homolo-

\footnotetext{
${ }^{13}$ BeHe, Darwin's Black Box..., s. 53.
} 
giczne do składników układu oddzielnie i pierwotnie petnity swoje wtasne funkcje.

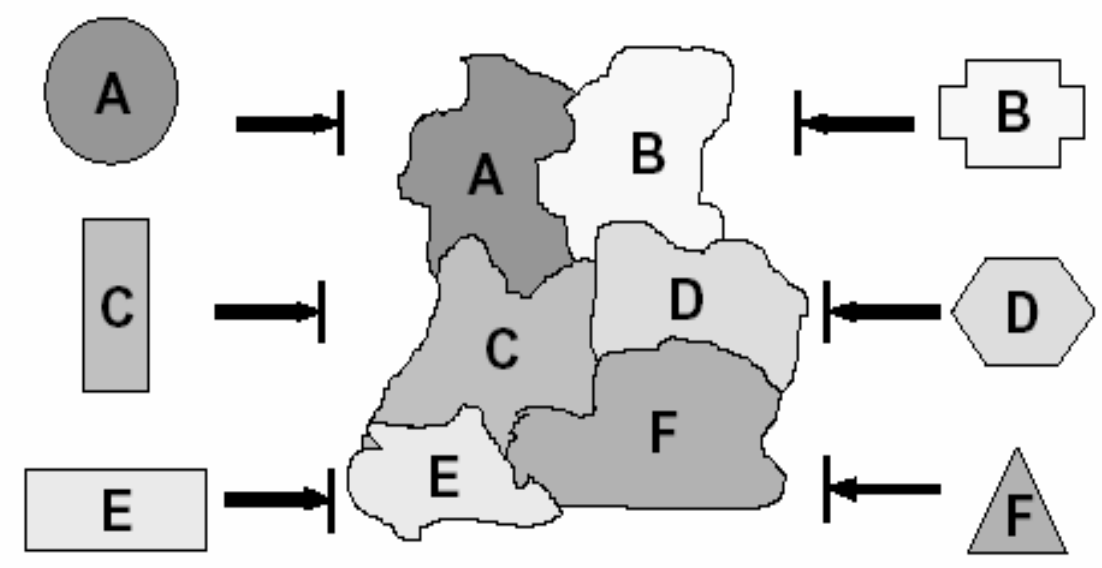

Rys. 2. Części nieredukowalnie złożonego mechanizmu molekularnego muszą mieć dobrze dopasowane do siebie powierzchnie, aby umożliwić specyficzne wiązanie. Ten rysunek wyraźnie pokazuje, że nawet jeśli funkcjonujące z osobna białka homologiczne do części jakiegoś układu pełniły pierwotnie oddzielne funkcje, to ich powierzchnie nie były w stosunku do siebie komplementarne. Dlatego problem nieredukowalności nie znika, nawet jeśli oddzielne części pełniły pierwotnie indywidualne funkcje. (Zablokowane strzałki wskazują na to, że pierwotne kształty białek nie są dostosowane do wiązania się z innymi białkami w mechanizmie molekularnym).

Nie należy też pochopnie wnioskować o redukowalności systemów posiadających dodatkowe, czyli redundantne składniki, mogą one bowiem posiadać nieredukowalnie złożony rdzeń. Na przykład, samochód $\mathrm{z}$ czterema świecami zapłonowymi może jeździć z trzema lub dwiema świecami, lecz z pewnością nie pojedzie bez żadnej. Pułapki na szczury mają często dwie sprężyny w celu zwiększenia ich siły. Taka pułapka może działać po usunięciu jednej sprężyny, ale nie będzie działała, gdy usunie się dwie. Przy próbie wyobrażenia sobie powstania pułapki na szczury za pomocą środków darwinowskich nadal natrafiamy na wszystkie problemy, które mieliśmy z pułapką na 
myszy. Przykładem redundancji w komórce jest ogromnie złożona rzęska eukariotyczna, składająca się z około 250 różnych części białkowych. ${ }^{14}$ Rzęska ma liczne kopie wielu swoich składników, łącznie $\mathrm{z}$ dużą ilością mikrotubul i ramion dyneinowych. Jednak, jak przedstawiłem w swojej książce, ${ }^{15}$ funkcjonująca rzęska potrzebuje do działania przynajmniej jednej kopii każdego ze składników. Dlatego, podobnie jak w przypadku pułapki na szczury, trudno sobie wyobrazić, jak mogła ona powstać w stopniowym, darwinowskim procesie. Kenneth Miller wskazuje redundantność rzęski jako kontrprzykład dla mojego twierdzenia o jej nieredukowalności. ${ }^{16}$ Lecz redundantność powoduje jedynie odłożenie kwestii nieredukowalności na później; nie eliminuje jej.

W końcu, zamiast pokazać, w jaki sposób ich teoria radzi sobie z tym problemem, darwiniści starają się obejść problem nieredukowalnej złożoności przy pomocy gierek słownych. Podczas debaty, sponsorowanej przez American Museum of Natural History, która odbyła się w kwietniu 2002 roku między zwolennikami i przeciwnikami teorii inteligentnego projektu, Kenneth Miller rzeczywiście stwierdził (kopia tej rozmowy jest dostępna na stronie internetowej National Center for Science Education), że pułapka na myszy nie jest nieredukowalnie złożona, gdyż jej podzbiory, a nawet każda osobna część, wciąż mogą „funkcjonować” niezależnie od tego układu. Miller zauważył, że drążek przytrzymujący z pułapki na myszy może służyć jako wykałaczka, a więc nadal pełni „funkcję”, nie będąc częścią pułapki na myszy. Wszystkich części pułapki można użyć jako przycisku do papieru - ciągnął dalej - więc każda z nich pełni jakieś „funkcje”. A skoro każdy przedmiot, który posiada masę, może posłużyć jako przycisk do papieru, to każda część czegokolwiek pełni swoją własną funkcję. Czary mary, nie istnieje nic takiego jak nieredukowalna zło-

\footnotetext{
${ }^{14}$ Por. S.K. Dutcher, „Flagellar Assembly in Two Hundred and Fifty Easy-to-Follow Steps", Trends in Genetics 1995, vol. 11, s. 398-404.

${ }^{15}$ Por. Behe, Darwin's Black Box..., s. 60.

${ }^{16}$ Por. Miller, Finding Darwin's God..., s. 140-143.
} 
żoność. W taki oto prosty sposób wyjaśniono poważny problem dla gradualizmu, który każde dziecko może dostrzec w systemach, takich jak pułapka na myszy.

Oczywiście, powyższe proste wyjaśnienie opiera się na ewidentnie błędnym przekonaniu, wyraźnej dwuznaczności. Miller używa słowa „funkcja” w dwóch różnych sensach. Przypomnijmy sobie, że definicja nieredukowalnej złożoności mówi, iż usunięcie jakiejś części „powoduje, że system przestaje sprawnie funkcjonować”. Nie wspominając o tym w swym wystąpieniu, Miller przenosi nacisk $\mathrm{z}$ osobnej funkcji samego nienaruszonego systemu na kwestię, czy możemy znaleźć inne zastosowanie (czy „funkcję”) dla niektórych jego $c z e ̨ s ́ c i$. Jeśli jednak usunie się jakąś część z przedstawionej przeze mnie pułapki, to nie złapie ona już myszy. System faktycznie przestaje sprawnie funkcjonować, a więc jest nieredukowalnie złożony - właśnie tak jak napisałem. Co więcej, funkcje tak łatwo przypisywane przez Millera częściom pułapki - przycisk do papieru, wykałaczka, łańcuszek na klucze i tak dalej - mają niewiele, albo nic wspólnego z funkcją całego układu - łapaniem myszy (w przeciwieństwie do serii pułapek na myszy zaproponowanej przez Johna McDonalda, którą omówię później) - a więc nie daje nam to żadnej wskazówki dla wyjaśnienia, w jaki sposób funkcja systemu mogła powstać stopniowo. Miller nie wyjaśnił właściwie niczego.

Pozostawiając problem pułapki na myszy za sobą, Miller przeszedł następnie do omówienia wici bakteryjnej - i ponownie odwołał się do tego samego błędnego przekonania. Jeżeli nie pozostało nic innego, należy podziwiać tę zapierającą dech zuchwałość próby słownego obrócenia kolejnego poważnego problemu darwinizmu na jego korzyść. W ostatnich latach wykazano, że wić bakteryjna jest znacznie bardziej skomplikowanym systemem niż dotąd sądzono. Działa ona nie tylko jako urządzenie o napędzie obrotowym, ale w jej skład wchodzi także wyszukany mechanizm transportujący białka $\mathrm{z}$ wewnątrz na zewnątrz komórki, tworzące wierzchni fragment wici. ${ }^{17}$ Miller bez zmrużenia

${ }^{17}$ S.I. AızawA, „Flagellar Assembly in Salmonella typhimurium”, Molecular Microbiol- 
oczu zapewnia, że wić nie jest nieredukowalnie złożona, gdyż pewnych białek wici może brakować, a pozostała reszta - być może niezależnie - może nadal transportować białka. (Białka podobne - ale nie identyczne - do białek znajdowanych w wici występują w systemie wydzielinowym typu III u niektórych bakterii). ${ }^{18}$ Miller ponownie popadł w dwuznaczność, przenosząc nacisk z funkcji układu, który działa jak maszyna o napędzie obrotowym, na zdolność podzbioru tego systemu do transportowania białek przez membranę. Jednak, jak argumentowałem, usunięcie części wici całkowicie odbiera temu układowi zdolność do funkcjonowania jak maszyna o napędzie obrotowym. Dlatego, niezgodnie z twierdzeniami Millera, wić rzeczywiście jest nieredukowalnie złożona. Co więcej, funkcja transportowania białek ma bezpośrednio tyle wspólnego z funkcją napędzania obrotowego, ile wykałaczka z pułapką na myszy. Tak więc odkrycie dodatkowej funkcji transportowania białek nie mówi nam niczego o tym, jak procesy darwinowskie mogły złożyć maszynę o napędzie obrotowym.

\section{Kaskada krzepnięcia krwi}

Uporawszy się $\mathrm{z}$ pewnymi powszechnymi nieporozumieniami, związanymi z hipotezą inteligentnego projektu, w kilku następnych paragrafach dokonam analizy dwóch układów, uznanych za poważne kontrprzykłady dla moich twierdzeń o nieredukowalnej złożoności. Nie tylko pokażę, że są to niedobre kontrprzykłady, ale przedstawię też, w jaki sposób podkreślają one powagę problemu, którym jest nieredukowalna złożoność.

ogy 1996, vol. 19, s. 1-5.

${ }^{18}$ Por. C.J. Hueck, „Type III Protein Secretion Systems in Bacterial Pathogens of Animals and Plants", Microbiology and Molecular Biology Reviews 1998, vol. 62, s. 379-433. 
W Darwin's Black Box argumentowałem, że kaskada krzepnięcia krwi stanowi przykład systemu nieredukowalnie złożonego. ${ }^{19} \mathrm{Na}$ pierwszy rzut oka krzepnięcie wydaje się prostym procesem. Małe rozcięcie lub zadrapanie przez chwilę pokrwawi, następnie krwawienie będzie powoli ustępować, aż zupełnie ustanie i powstaną widoczne skrzepy krwi. Jednakże badania z ostatnich pięćdziesięciu lat pokazały, że pod powierzchowną prostotą kryje się system o niezwykłej złożoności. ${ }^{20} \mathrm{~W}$ sumie w układ krzepnięcia u kręgowców zaangażowanych jest ponad dwadzieścia oddzielnych części białkowych. Wspólne działanie składników ma swój rezultat w utworzeniu w miejscu rozcięcia pajęczynowatej struktury, która więzi krwinki czerwone i zatrzymuje krwawienie. Większość składników kaskady krzepnięcia nie wchodzi w skład struktury samego skrzepu, lecz kontroluje jego umiejscowienie i czas realizacji poszczególnych etapów tego procesu. Ostatecznie, nie byłoby dobrze, gdyby skrzepy formowały się $w$ nieodpowiednim czasie i miejscu. Utworzenie skrzepu w złym miejscu, takim jak serce czy mózg, mogłoby doprowadzić do zawału serca lub udaru. Ale nawet jeśli skrzep uformuje się we właściwym miejscu, lecz zbyt wolno, również nie będzie to dobra sytuacja.

Nierozpuszczalne, pajęczynowate włókna materiału, z którego składa się sam skrzep, tworzy białko zwane fibryną. Jednakże nierozpuszczalna pajęczyna zatamowałaby przepływ krwi przed nastąpieniem skaleczenia, a więc fibryna istnieje w krwiobiegu początkowo w rozpuszczalnej, nieaktywnej formie zwanej fibrynogenem. Gdy zamknięty system krążenia jest uszkodzony, fibrynogen zostaje uaktywniony przez odcięcie jednego końca $u$ dwóch $z$ trzech białek, które go tworzą. Odsłonięte zostają lepkie miejsca na białku, co umożliwia im łączenie się. Z powodu kształtu fibryny molekuły łączą się w długie włókna, które formują strukturę skrzepu. Ostatecznie, gdy

\footnotetext{
${ }^{19}$ Por. Behe, Darwin's Black Box..., s. 74-97.

${ }^{20} \mathrm{~T}$. HaLKIER, Mechanisms in Blood Coagulation Fibrinolysis and the Complement System, Cambridge University Press, Cambridge 1992.
} 
zakończy się zdrowienie, skrzep zostaje usunięty przez enzym zwany plazminą.

Enzym przetwarzający fibrynogen w fibrynę nazywany jest trombiną. Działanie trombiny musi być jednak dokładnie regulowane. Gdyby nie było, trombina szybko przemieniłaby fibrynogen w fibrynę, powodując masowe tworzenie się skrzepów krwi i natychmiastową śmierć. Okazuje się, że trombina istnieje w nieaktywnej formie zwanej protrombiną, którą musi aktywować inny składnik, nazywany czynnikiem Stuarta. Podążając takim samym tropem, działanie czynnika Stuarta również musi być kontrolowane, a aktywuje go jeszcze inny składnik. Ostatecznie, składnik zwykle rozpoczynający kaskadę to czynnik tkankowy, który występuje na komórkach normalnie nie wchodzących w kontakt $\mathrm{z}$ układem krążenia. Jednak gdy nastąpi skaleczenie, krew kontaktuje się z czynnikiem tkankowym, co zapoczątkowuje kaskadę krzepnięcia.

W kaskadzie krzepnięcia krwi jeden składnik wpływa więc na inny, który oddziałuje na następny i tak dalej. Argumentowałem, że kaskada jest nieredukowalnie złożona, ponieważ gdy usunie się jakiś jej składnik, ów proces albo natychmiast się włącza, albo definitywnie wyłącza. Na nic się zdaje - pisałem - postulat, że proces ten rozpoczął się od jednego czynnika, fibrynogenu, po czym dodano inne składniki, gdyż sam fibrynogen do niczego się nie przydaje. Nie warto też zaczynać nawet od czegoś w rodzaju fibrynogenu i niespecyficznego enzymu, który mógłby go rozszczepić, ponieważ krzepnięcie nie byłoby regulowane i możliwe, że czyniłoby więcej szkody niż pożytku.

Tak twierdzę ja. Jednak Russell Doolittle - wybitny biochemik zajmujący się białkami, profesor biochemii w University of California w San Diego, członek National Academy of Sciences, badający przez całe życie system krzepnięcia krwi - nie zgadza się ze mną. Doolittle napisał esej na sympozjum, dotyczący mojej książki i książki Richarda Dawkinsa Wspinaczka na szczyt nieprawdopodobieństwa. Materiały sympozjum zostały opublikowane w wydawanym przez Massachusetts Institute of Technology Boston Review. W eseju tym 
omawiane jest zjawisko duplikacji genu, dzięki któremu komórka może zaopatrzyć się w dodatkową kopię funkcjonującego genu. Doolittle wysunął przypuszczenie, że składniki procesu krzepnięcia krwi, z których wiele ma strukturę podobną do siebie nawzajem, powstały przez duplikację genu i stopniową dywergencję. Jest to rozpowszechniony pogląd wśród darwinistów. Profesor Doolittle opisał przeprowadzony niedawno temu eksperyment pokazujący - jak sądzi - że kaskada wcale nie jest nieredukowalna. Doolitlle odniósł się do rozprawy napisanej przez Bugge'ego et al., ${ }^{21}$ zatytułowanej „Loss of fibrinogen rescues mice from the pleiotropic effects of plasminogen deficiency" [Utrata fibrynogenu ratuje myszy przed plejotropowymi skutkami niedoboru plazminogenu]. Pisał o niej:

\begin{abstract}
Ostatnio znokautowano ** u myszy gen dla plaminogenu [sic] i - jak można było się spodziewać - zaczęły one cierpieć na powikłania trombotyczne, ponieważ nie były zdolne do usunięcia skrzepów fibrynowych. Niedługo potem ci sami badacze znokautowali gen dla fibrynogenu u innej populacji myszy. Znowu - jak można było przewidzieć - myszy zachorowały, choć tym razem problem stanowił krwotok. A jak sądzicie, co się stało, gdy skrzyżowano te dwie populacje? Praktycznie rzecz biorąc myszy pozbawione obu genów były normalne! Niezgodnie z twierdzeniami o nieredukowalnej złożoności, nie potrzeba całego zespołu białek. Muzyka i harmonia mogą powstać z mniejszej orkiestry. ${ }^{22}$
\end{abstract}

(Przypominam, że fibrynogen jest prekursorem samego materiału, z którego zbudowany jest skrzep, a plazminogen jest prekursorem plazminy, która usuwa skrzepy, gdy spełnią one swoje zadanie). Jeśli

${ }^{21}$ T.H. Bugge, K.W. Kombrinck, M.J Flick, C.C. Daugherty, M.J. Danton \& J.L. Degen, „Loss of Fibrinogen Rescues Mice from the Pleiotropic Effects of Plasminogen Deficiency”, Cell 1996, vol. 87, s. 709-719.

** (Przypis thumacza) Usunięcie z genomu jakiegoś genu specjaliści określają jako „nokaut" (od ang. knock-out) - termin zapożyczony z żargonu bokserskiego. O organizmach, którym usunięto jakiś gen, mówi się, że są ,znokautowane”.

${ }^{22}$ Russell F. Doolitrle, „Subtelna równowaga”, przeł. Dariusz Sagan, Filozoficzne Aspekty Genezy 2004, t. 1, s. 63-64 [55-64], http://www.nauka-a-religia.uz.zgora.pl/index.php? action=tekst\&id=52. 
więc znokautuje się któryś $\mathrm{z}$ tych genów procesu krzepnięcia, to pojawią się problemy; jeżeli jednak, zapewnia Doolittle, znokautuje się oba geny, system znowu będzie wyraźnie funkcjonalny. Choć byłby to bardzo interesujący wynik, okazuje się, że tak nie jest. Doolittle błędnie zinterpretował tę rozprawę.

W abstrakcie artykułu Bugge'ego et al. ${ }^{23}$ pojawia się stwierdzenie, że „Myszy pozbawione plazminogenu i fibrynogenu są fenotypowo nieodróżnialne od myszy pobawionych tylko fibrynogenu". Innymi słowy, myszy, którym usunięto dwa geny cierpią na wszystkie te dolegliwości, co myszy pozbawione wyłącznie fibrynogenu. Dolegliwości owe obejmują niezdolność do formowania się skrzepów, krwotok i śmierć samic w ciąży. Niedobór plazminogenu prowadzi do innego zbioru symptomów - trombozy, wrzodów i wysokiej śmiertelności. Myszy pozbawione obu genów „ratowano” przed skutkami chorobowymi niedoboru plazminogenu w ten sposób, że cierpiały one tylko na dolegliwości związane $\mathrm{z}$ niedoborem fibrynogenu. ${ }^{24}$ Powód tego łatwo zrozumieć. Plazminogen jest potrzebny do usuwania skrzepów, które - nie usunięte - zakłócają normalne funkcjonowanie. Jednakże, jeśli znokautowany jest także gen dla fibrynogenu, to skrzepy nie mogą się w ogóle formować i nie trzeba ich usuwać. Jeżeli jednak skrzepy nie mogą powstawać, to nie istnieje żaden funkcjonalny system krzepnięcia, a myszy cierpią z powodu przewidywalnych następstw.

Myszy, którym usunięto dwa geny, najwyraźniej nie są „normalne". Nie stanowią obiecujących form przejściowych w procesie ewolucji.

Ta sama grupa badaczy, która stworzyła myszy pozbawione plazminogenu i fibrynogenu, stworzyła również myszy indywidualnie

\footnotetext{
${ }^{23}$ BugGe et al., „Loss of fibrinogen...”.

${ }^{24}$ Bugge'ego et al. interesowało to, czy plazminogen odgrywa jakąkolwiek inną rolę w metabolizmie niż - jak dotąd zakładano - tylko rolę w krzepnięciu. Fakt, że bezpośrednie skutki niedoboru plazminogenu łagodził niedobór fibrynogenu pokazuje, że plazminogen prawdopodobnie nie pełni żadnej innej funkcji.
} 
pozbawione innych składników kaskady krzepnięcia - protrombiny i czynnika tkankowego. W obu przypadkach zwierzęta te są poważnie upośledzone, a dokładnie tego należy się spodziewać, jeśli kaskada jest nieredukowalnie złożona (tabela 1).

Tabela 1. Skutki znokautowania genów dla składników systemu krzepnięcia krwi.

\begin{tabular}{lll} 
brakujące białko & \multicolumn{1}{c}{ symptomy } & bibliografia \\
plazminogen & tromboza, wysoka umieralność & Bugge et al. ${ }^{25}$ \\
fibrynogen & krwotok, śmierć samic w ciąży & Suh et al. ${ }^{26}$ \\
plazminogen/fibrynogen & krwotok, śmierć samic w ciąży & Bugge et al. ${ }^{27}$ \\
protrombina & krwotok, śmierć samic w ciąży & Sun et al. ${ }^{28}$ \\
czynnik tkankowy & krwotok, śmierć samic w ciąży & Bugge et al. ${ }^{29}$
\end{tabular}

Jaką naukę możemy stąd wyciągnąć? Z pewnością nie chodzi o to, że Russell Doolittle błędnie zinterpretował rozprawę, co może się zdarzyć każdemu. (Naukowcy z reguły nie słyną z jasnego pisania, a Bugge et al. nie stanowią wyjątku). Głównie możemy się z tego nauczyć,

\footnotetext{
${ }^{25}$ T.H. Bugge, M.J. Flick, C.C. Daugherty \& J.L. Deggen, „Plasminogen Deficiency Causes Severe Thrombosis But is Compatible with Development and Reproduction", Genes and Development 1995, vol. 9, s. 794-807.

${ }^{26}$ T.T. Suh, K. Holmback, N.J. Jensen, C.C. Daugherty, K. Small, D.I. Simon, S. Potter \& J.L. Degen, „Resolution of Spontaneous Bleeding Events But Failure of Pregnancy in Fibrinogen-Deficient Mice", Genes and Development 1995, vol. 9, 2020-2033.

${ }^{27}$ BugGe et al., „Loss of fibrinogen...”.

${ }^{28}$ W.Y. Sun, D.P White, J.L. Degen, M.C. Colbert, M.C. Burkart, K. Holmback, Q. Xiao, T.H. Bugge \& S.J. Degen, „Prothrombin Deficiency Results in Embryonic and Neonatal Lethality in Mice", Proceedings of the National Academy of Sciences of the United States of America 1998, vol. 95, s. 7597-7602.

${ }^{29}$ T.H. Bugge, Q. Xiao, K.W. Kombrinck, M.J. Flick, K. Holmback, M.J. Danton, M.C. Colbert, D.P. White, K. Fujikawa, E.W. Davie \& J.L. Degen, „Fatal Embryonic Bleeding Events in Mice Lacking Tissue Factor, the Cell-Associated Initiator of Blood Coagulation", Proceedings of the National Academy of Sciences of the United States of America 1996, vol. 93, s. 6258-6263.
} 
że nieredukowalna złożoność wydaje się o wiele poważniejszym problemem, niż sądzą darwiniści, skoro eksperyment - wybrany przez Doolittle'a do zademonstrowania, że „muzyka i harmonia mogą powstać z mniejszej orkiestry" - pokazał, iż jest wręcz przeciwnie. Drugą nauką jest to, że duplikacja genu nie stanowi panaceum, jak się często utrzymuje. Profesor Doolittle wie o strukturach białek procesu krzepnięcia więcej niż ktokolwiek inny na świecie i jest przekonany, że wiele z nich powstało przez duplikację genu i tasowanie eksonów. Mimo to owa wiedza nie uchroniła go przed zaproponowaniem zupełnie nierealnych mutantów jako możliwych przykładów form przejściowych w procesie ewolucji. Trzecia nauka jest taka, że - jak twierdziłem w Darwin's Black Box - w literaturze naukowej nie ma żadnych rozpraw, które szczegółowo opisywałyby, w jaki sposób proces krzepnięcia mógł powstać za pomocą środków darwinowskich. Gdyby takie istniały, Doolittle z pewnością zacytowałby je.

Jeszcze inną nauką, jaką możemy stąd wyciągnąć, jest to, że choć większość biologów akademickich i filozofów ma zaufanie do darwinizmu, nie jest ono solidniej ugruntowane niż w przypadku profesora Doolittle'a. Za ilustrację niech posłużą nam słowa filozofa Michaela Ruse'a:

Behe na przykład jest prawdziwym naukowcem, lecz argument na rzecz niemożliwości naturalnego powstania małymi krokami złożoności biologicznej z pogardą odrzucili uczeni pracujący w tej dziedzinie. Uważają oni, że Behe słabo rozumie swoją dziedzinę, a jego znajomość literatury jest dziwnie (choć to dla niego wygodne) przestarzała.

Ewolucja układu krzepnięcia nie jest żadną zagadką. Na przykład minione trzy dekady pracy Russella Doolittle’a i innych rzuciły znaczące światło na drogi powstawania procesu krzepnięcia. Ponadto, można pokazać, że mechanizm krzepnięcia nie musi być zjawiskiem jednoetapowym, gdzie wszystko jest już obecne i funkcjonuje. Jeden krok w kaskadzie obejmuje fibrynogen, potrzebny przy krzepnięciu, a drugi, plaminogen [sic], potrzebny przy usuwaniu skrzepów. ${ }^{30}$

\footnotetext{
${ }^{30}$ Michael Ruse, ,Answering the Creationists: Where They Go Wrong and What They're
} 
W tym miejscu Ruse zacytował fragment recenzji Doolittle'a $z$ Boston Review, który ja przytoczyłem wcześniej w tym artykule. Ruse jest czołowym darwinistą i napisał wiele książek traktujących o różnych aspektach darwinizmu. Mimo to, jak pokazuje jego pełne aprobaty przytoczenie błędnego rozumowania Doolittle’a (łącznie z powtórzeniem błędu drukarskiego - chodzi o „plaminogen”), Ruse nie posiada niezależnej wiedzy o tym, jak dobór naturalny mógł wytworzyć złożone systemy biochemiczne. Ruse nie ma nic do dodania do dysputy naukowców.

Inny taki przykład można zobaczyć w niedawno opublikowanym w The Scientist eseju zatytułowanym „Not-So-Intelligent Design” [Nie-taki-znowu-inteligentny projekt], autorstwa Neila S. Greenspana, profesora patologii w Case Western Reserve University, który napisał: ${ }^{31}$ „Zwolennicy Projektu ignorują również nagromadzone przykłady redukowalnych układów biologicznych. Jak zauważył Russell Doolittle, komentując pisma jednego z popleczników ID..." - i Greenspan z uznaniem przytacza w tym miejscu argument Doolittle'a zaczęrpnięty z Boston Review. Z mimowolną ironią skonkludował, że „Te wyniki rzucają cień wątpliwości na twierdzenie zwolenników ID, iż wiedzą oni, które systemy są nieredukowalnie złożone, a które nie". Ale skoro wyniki badań przeprowadzonych przez Bugge'ego et al. ${ }^{32}$ wykazują dokładnie coś przeciwnego, niż przypuszczał Greenspan, to racja leży po drugiej stronie. Incydent ten wywołuje poważne wątpliwości co do twierdzenia darwinistów - zarówno biologów i filozofów - że wiedzą oni, iż złożone układy komórkowe można wyjaśnić w kategoriach darwinowskich. Pokazuje on, że darwiniści albo nie potrafią, albo nie chcą przyznać, że ich teoria boryka się z pewnymi trudnościami.

Afraid of', Free Inquiry 1998, March 22, s. 28.

${ }^{31}$ Neil S. GreensPan, „Not-So-Intelligent Design”, The Scientist 2002, vol. 16, s. 12.

${ }^{32}$ Bugge et al., „Loss of fibrinogen...”. 


\section{Pulapka na myszy}

Drugi kontrargument dla nieredukowalności, jaki tutaj omówię, nie dotyczy przykładu biologicznego. W Darwin's Black Box jako przykład nieredukowalnej złożoności wskazałem pospolitą mechaniczną pułapkę na myszy. Niemal natychmiast po publikacji książki niektórzy darwiniści zaczęli proponować sposoby, którymi można krok po kroku zbudować pułapkę na myszy. Jedną z tych propozycji, która zyskała sporo uwagi i została zaaprobowana przez niektórych wybitnych uczonych, przedstawił i zamieścił na swojej stronie internetowej ${ }^{33}$ John McDonald, profesor biologii w University of Delaware. Serię zaprojektowanych przez niego pułapek pokazuje rysunek 3. McDonald chciał przede wszystkim wykazać, że można zbudować pułapkę, składającą się z mniejszej ilości części, niż przedstawiona w mojej książce pułapka pięcioczęściowa.

Zgoda. W rzeczywistości właśnie tak powiedziałem w swojej książce. Napisałem:

Należy odróżnić prekursora fizycznego od prekursora pojęciowego. Opisana powyżej pułapka nie jest jedynym systemem, który może unieruchomić mysz. Przy innych okazjach moja rodzina stosowała lep. Przynajmniej teoretycznie da się użyć otwartego pudełka opartego o kij, który można potrącić. Można też po prostu zastrzelić mysz z wiatrówki. Nie są to jednak prekursory fizyczne standardowej pułapki na myszy, ponieważ nie da się ich przekształcić krok-po-darwinowskim-kroku $\mathrm{w}$ pułapkę z podstawą, młoteczkiem, sprężyną, zapadką $\mathrm{i}$ drążkiem przytrzymującym. ${ }^{34}$

\footnotetext{
${ }^{33} \mathrm{http} / / / \mathrm{udel} . \mathrm{edu} / \sim$ mcdonald/oldmousetrap.html. Profesor McDonald zaprojektował ostatnio nową serię pułapek, które można zobaczyć na stronie http://udel.edu/ mcdonald/ mousetrap.html. Przeanalizowałem je i wnioskuję, że wymagają one inteligentnego kierownictwa McDonalda w tym samym stopniu, co wcześniejsze pułapki.

${ }^{34}$ BeHe, Darwin's Black Box..., s. 43.
} 

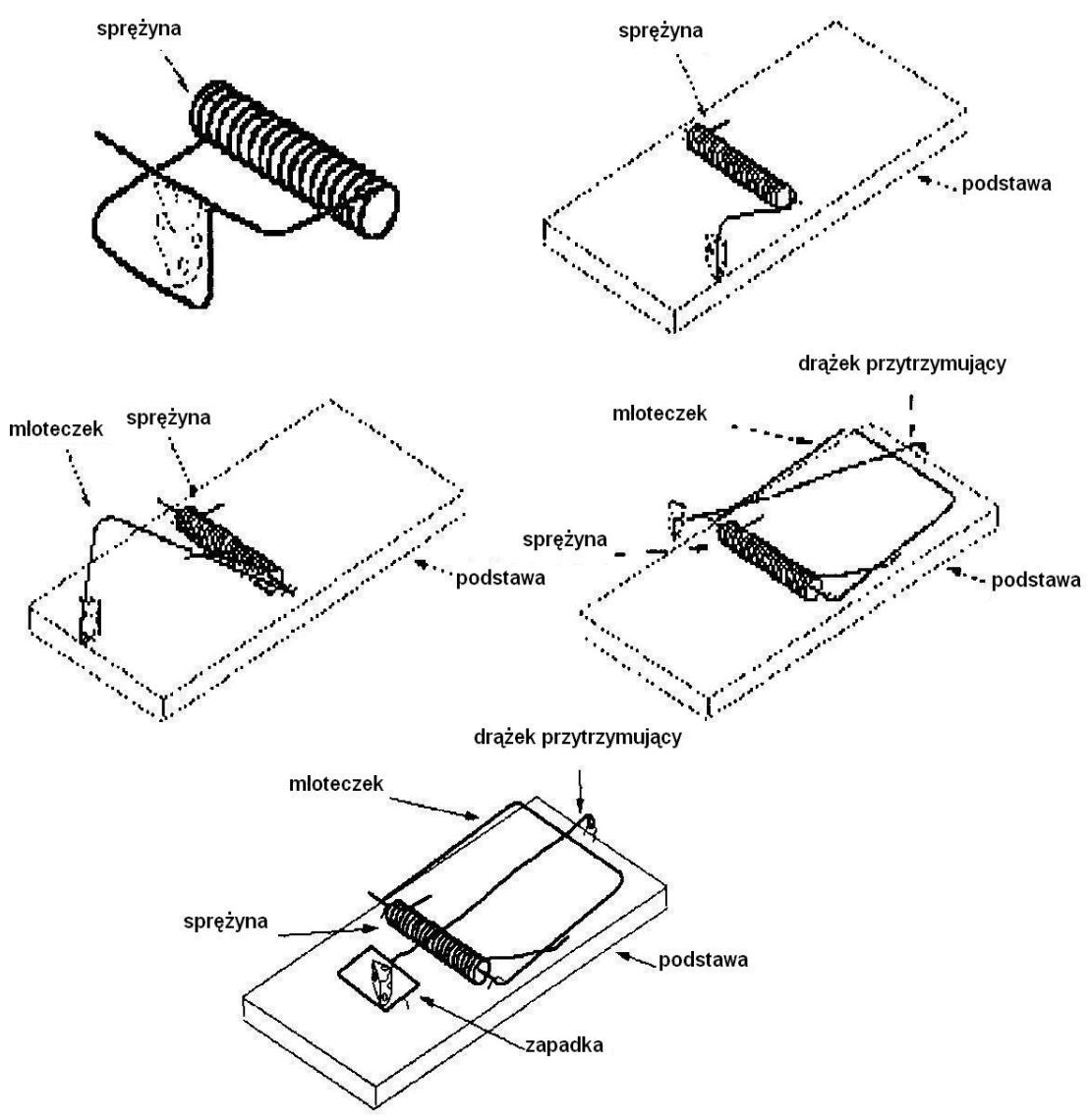

Rys. 3. Seria pułapek na myszy ze wzrastającą liczbą części, w formie zaproponowanej przez Johna McDonalda (http://udel.edu/ mcdonald/oldmousetrap.html) i reprodukowana tu za jego zgoda. Tekst świadczy jednak, że aby przekonstruować jedną pułapkę $w$ drugą, ciągle potrzebna jest inteligencja.

Nie chodzi więc o to, że pułapki na myszy można budować na różne sposoby, z różną ilością części. (Moje dzieci mają $\mathrm{w}$ domu grę o nazwie „Pułapka na myszy”, która ma wiele części i wygląda zupełnie inaczej niż pospolita mechaniczna pułapka). Oczywiście, że można. 
Pytanie tylko, czy można zbudować jakąś konkretną pułapkę poprzez „liczne, następujące po sobie, drobne przekształcenia” - jak postulował Darwin - od prostego punktu początkowego, bez udziału inteligencji?

Pułapek McDonalda nie da się skonstruować w ten sposób. $\mathrm{Na}$ samej górze rysunku 3 pokazano jego jedno- i dwuczęściową pułapkę. Budowa drugiej pułapki nie stanowi jednak pojedynczego, małego, przypadkowego przejścia od pierwszej pułapki. Zauważmy po pierwsze, że pułapka jednocześciowa nie jest zwykłą sprężyną - została specjalnie ukształtowana. W rzeczywistości, aby mogła działać jak pułapka, jej kształt rozmyślnie dobrał inteligentny czynnik - John McDonald. Cóż, od czegoś trzeba zacząć. Lecz jeśli ta seria pułapek na myszy w ogóle ma mieć jakiś związek z ewolucją darwinowską, to nie można mieszać inteligencji w żadne $\mathrm{z}$ następnych przejść.

Jednakże inteligencja widoczna jest w całej serii. Rozważmy, co byłoby konieczne do przekształcenia pułapki jednoczęściowej $\mathrm{W}$ „dwuczęściową". Nie można po prostu umieścić pierwszej pułapki na zwykłym kawałku drewna i otrzymać sprawnej drugiej pułapki. Raczej, jak pokazuje rysunek 3, obie wystające końcówki sprężyny należy najpierw ustawić w innym kierunku. Co więcej, dodano dwie zszywki (ledwo widoczne na rysunku 3), by przytrzymać sprężynę na podstawie $\mathrm{w}$ ten sposób, żeby w dwuczęściowej pułapce była ona naprężona. Przeszliśmy więc nie od jedno- do dwuczęściowej pułapki, lecz od pułapki jedno- do czteroczęściowej. Zauważmy również, że istotne jest umiejscowienie zszywek w stosunku do krawędzi podstawy. Gdyby je przesunąć o ćwierć cala, pułapka by nie działała. $\mathrm{Na}$ koniec odnotujmy, że aby mieć poważną analogię do mechanicznych procesów komórkowych, pułapki na myszy nie może złożyć jakiś inteligentny czynnik - pierwszą pułapkę musiałby zbudować pewien nieświadomie kierujący mechanizm. Przy zmianie ułożenia części, mechanizm kierujący także musiałby się więc zmienić dla drugiej pulapki. 
Łatwo nam - działającym inteligentnie - przeoczyć naszą rolę $\mathrm{w}$ kierowaniu konstruowaniem jakiegoś systemu, ale przyroda nie może przeoczyć żadnego kroku. Zaproponowana przez McDonalda seria pułapek na myszy nie jest więc dobrą analogią ewolucji darwinowskiej. W rzeczywistości, drugą pułapkę lepiej uważać nie za jakiegoś darwinowskiego potomka pierwszej, lecz za całkowicie inną pułapkę, zaprojektowaną przez pewien inteligentny czynnik, który, być może, użył jednej lub dwóch przemodelowanych części pierwszej pułapki.

Z każdym kolejnym krokiem tej serii wiążą się analogiczne problemy, które omówiłem gdzie indziej. ${ }^{35}$

Popierając McDonaldowską serię pułapek na myszy, Kenneth Miller napisał: „Jeżeli można pokazać, że prostsze wersje tego mechanicznego urządzenia [pułapki na myszy] funkcjonują, to prostsze wersje mechanizmów biochemicznych również mogą funkcjonować [...] a to znaczy, że złożone mechanizmy biochemiczne faktycznie mogły mieć funkcjonalne prekursory". ${ }^{36}$ Ale tego właśnie owe serie nie pokazują - jeśli pod pojęciem „,prekursora” Miller rozumie ,prekursora darwinowskiego". Przeciwnie, serie te dają do zrozumienia, że nawet jeśli ktoś znajdzie prostszy system pełniący pewną funkcję, to i tak nie będziemy mieli żadnego powodu, by sądzić, że jakiś bardziej złożony darwinowski proces mógł wytworzyć układ pełniący tę samą funkcję, zaczynając od systemu prostszego. Trudność wykonania tej operacji na prostej pułapce na myszy daje nam przekonujący powód, by sądzić, że nie da się tego zrobić, gdy w grę wchodzą złożone mechanizmy molekularne.

\footnotetext{
${ }^{35}$ Michael J. BeHE, „A Mousetrap Defended: Response to Critics”, http://www.discov ery.org/scripts/viewDB/index.php?command=view\&id=446.

${ }^{36} \mathrm{http}$ ///biocrs.biomed.brown.edu/Darwin/DI/Mousetrap.html.
} 


\section{Perspektywy hipotezy inteligentnego projektu}

Błędne argumenty darwinistów, które tutaj obszernie opisałem, utwierdzają mnie tylko w przekonaniu, że hipoteza inteligentnego projektu jest na właściwej drodze. W końcu, jeśli dobrze poinformowani oponenci pewnej idei atakują ją, posiłkując się danymi, które - obiektywnie rozważone - naprawdę ukazują jej siłę, to możemy przypuszczać, że tę ideę warto badać.

Jednakże to nie głównie nieadekwatność odpowiedzi darwinistów dobrze wróży hipotezie projektu. Siła projektu bierze się przede wszystkim z codziennego postępu nauki. Aby docenić ów fakt, należy zdać sobie sprawę $\mathrm{z}$ tego, że idea inteligentnego projektu nie wyłoniła się z pracy jakiegoś indywiduum, lecz ze zbiorowego wysiłku biologów, zwłaszcza w ciągu minionych pięćdziesięciu lat. Pięćdziesiąt lat temu komórka wydawała się o wiele mniej złożona i łatwiej było wtedy naiwnie myśleć, że jej pochodzenie mogą wyjaśnić procesy darwinowskie. Jednak wraz z rozwojem biologii, gdy okazało się, iż komórka jest niezwykle złożona, idea projektu stała się coraz bardziej frapująca. Ten trend jest niepowstrzymanie kontynuowany. Komórka nie staje ani trochę prostsza, a wręcz przeciwnie - coraz bardziej złożona. Zakończę ten rozdział, przytaczając tylko jeden przykład ze względnie nowej dziedziny proteomiki.

Po pomyślnym zsekwencjonowaniu całych genomów setek mikroorganizmów i jednego kręgowca (nas), natychmiast zajęto się analizowaniem komórkowych interakcji białek ujmowanych jako całość, dla których zakodowane są genomy. Dokonano już zadziwiającego postępu. Na początku 2002 roku ogłoszono wyczerpujące wyniki badań nad białkami zawierającymi proteom drożdżowy. Między innymi, badacze zapytali, jaki odsetek białek drożdżowych pracuje w grupach. Odkryli oni, że blisko pięćdziesiąt z nich działa w 
kompleksach liczących pół tuzina lub więcej białek, a wiele w kompleksach liczących dziesięć lub więcej białek. ${ }^{37}$

Nie tego oczekiwali darwiniści. Bruce Alberts napisał kiedyś w artykule „The Cell as a Collection of Protein Machines” [Komórka jako zbiorowisko mechanizmów białkowych]:

Nigdy nie docenialiśmy komórek. Bez wątpienia nie doceniamy ich nadal. Ale przynajmniej nie jesteśmy już tak naiwni, jak byliśmy za czasów, gdy ukończyłem studia w latach 60 -tych. Większość z nas postrzegała wtedy komórki jako zawierające olbrzymi zbiór drugorzędnych reakcji [...]

Jednak, jak się okazało, możemy chodzić i mówić, ponieważ chemia umożliwiająca życie jest o wiele bardziej wyszukana i skomplikowana, niż cokolwiek, nad czym my - studenci - kiedykolwiek rozmyślaliśmy. Białka stanowią większość suchej masy komórki. Komórka nie jest jednak zdominowana przez przypadkowo zderzające się pojedyncze cząsteczki białka. Wiemy teraz, że prawie każdy główny proces w komórce przeprowadzają grupy 10 lub więcej molekuł białkowych. Pełniąc swoją biologiczną funkcję, każda grupa białkowa oddziałuje z kilkoma innymi dużymi kompleksami białek. W istocie całą komórkę można postrzegać jako fabrykę, która jest wyposażona w skomplikowaną sieć powiązanych ze sobą zespołów lin, z których każda składa się ze zbioru dużych mechanizmów białkowych. ${ }^{38}$

Dla teorii inteligentnego projektu ważny jest tutaj fakt, że mechanizmy molekularne nie ograniczają się do kilku przykładów, które omówiłem w Darwin's Black Box. Wygląda na to, że większość białek to składniki skomplikowanych mechanizmów molekularnych.

${ }^{37}$ A.C. Gavin, M. Bosche, R. Krause, P. Grandi, M. Marzioch, A. Bauer, J. Schultz, J.M. Rick, A.M. Michon, C.M. Cruciat, M. Remor, C. Hofert, M. Schleider, M. Brajenovic, H. Ruffner, A. Merino, K. Klein, M. Hudak, D. Dickson, T. Rudi, V. Gnau, A. Bauch, S. Bastuck, B. Huhse, C. Leutwein, M.A. Heurtier, R.R. Copley, A. Edelmann, E. Querfurth, V. Rybin, G. Drewes, M. Raida, T. Boummeester, P. Bork, B. Seraphin, B. Kuster, G. Neubauer \& G. Superti-Furga, „Functional Organization of the Yeast Proteome by Systematic Analysis of Protein Complexes", Nature 2002, vol. 415, s. 141-147.

${ }^{38}$ Bruce Alberts, „The Cell as a Collection of Protein Machines: Preparing the Next Generation of Molecular Biologists”, Cell 1998, vol. 92, s. 291-294. 
Projekt można by więc rozszerzyć na dużą część cech komórki, a może nawet poza jej obszar - na wyższe poziomy biologii.

Rozwój dwudziestowiecznej nauki doprowadził nas do hipotezy projektu. Spodziewam się, że rozwój nauki XXI wieku potwierdzi ją i poszerzy jej zakres.

Michael J. Behe 